OCTOBER 1999 - VOLUME 38 -NUMBER 4

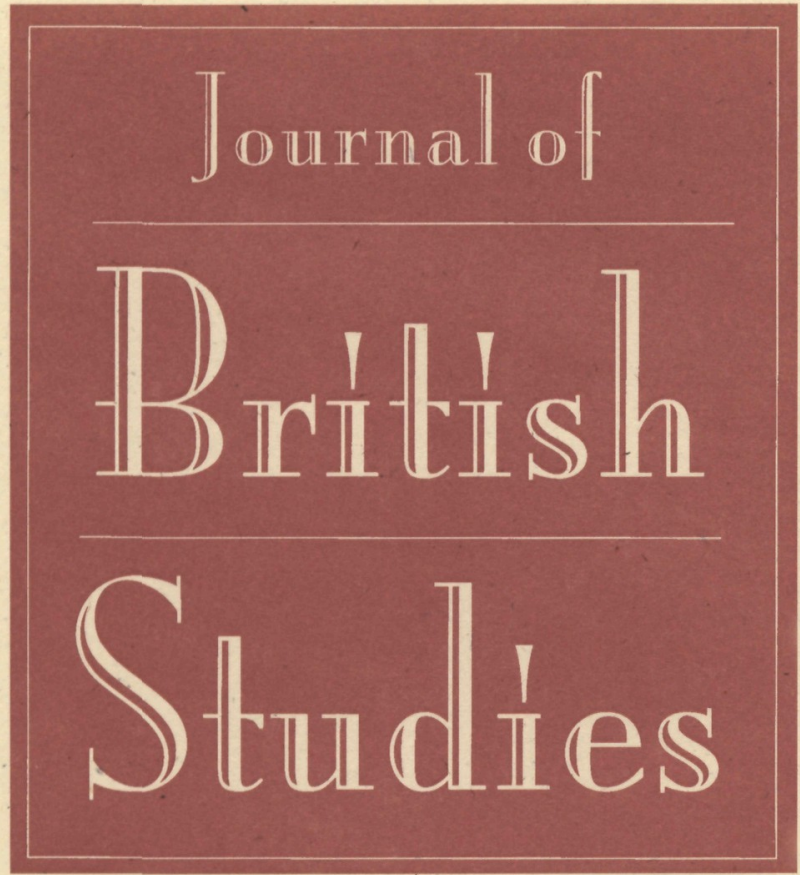

THE UNIVERSITY OF CHICAGO PRESS 
EDITOR

Margot Finn

Emory University

ASSISTANT EDITOR

Jeffrey S. Reznick

\section{BOARD OF ADVISORS}

Jean Allman

University of Minnesota

Donna T. Andrew

Guelph University

Peter Bailey

University of Manitoba

George K. Behlmer

University of Washington

Thomas Cogswell

University of Kentucky

David Cressy

Ohio State University,

Frances E. Dolan

University of Miami

James S. Donnelly, Jr.

University of Wisconsin-Madison
Thomas A. Green

University of Michigan, Ann Arbor

J. G. H: Hudson

University of St. Andrews

Steven Justice

University of California, Berkeley

Peter Lake

Princeton University

Deborah Epstein Nord

Princeton University

Susan Pedersen

Harvard University

Pat Thane

University of Sussex

Deborah Valenze

Columbia University

NǪRTH AMERICANN CONFERENCE ON BRITISH STUDIES

President Fred M. Leventhal

Boston University

Immediate Past-President Walter L. Arnstein

University of llinois at Champaign-Urbana

Viçe President Linda Levy Peck

George Washington University

Executive Secretary Brian P. Levack

University of Texas at Austin

Associate Executive Secretary Patricia Seleski

California State University at San Marcos

Treasurer Marc Baer

Hope College

The paper used in this publication meets the minimum requirements of American National Standard for Information Sciences-Permanence of Paper for Printed Library Materials, ANSI Z39.48-1984.@ 


\section{Journal of British Studies}

Contents

Volume $38 \quad$ Number 4

October 1999

Women, Posthumous Benefaction, and Family Strategy in

Pre-Conquest England

JULIA CRICK

The Dissidence of Despair: Rebellion and Identity in Early

Modern Cornwall

Mark Stoyle

Chartism Remembered: William Aitken, Liberalism, and the

Politics of Memory

Robert G. Hall

\section{Reviews}

Gender, Commerce, and Service: Society and the Economy in

Eighteenth-Century England

VIVIEN E. DiETZ

Sex, Soap, and Colonial Studies

LUISE WHITE

The Labour Party and the Politics of Democracy

Steven Fielding

Contents of Volume 38 
Journal of British Studies (ISSN 0021-9371) is published four times a year, in January, April, July, and October, by The University of Chicago Press, $5720 \mathrm{~S}$. Woodlawn Avenue, Chicago, Illinois 60637, sponsored by the North American Conference on British Studies.

Membership and Subscription Rates: NACBS DUES INCLUDING JBS SUBSCRIPTION: 1 year, USA: members, $\$ 70.00$; students (with copy of validated ID), $\$ 41.00$. Canada: members, $\$ 79.54$; students, $\$ 46.37$. Outside the U.S. and Canada, add $\$ 2.50$ for postage for each year's subscription. NACBS DUES ONLY (includes subscription to Albion and to British Studies Intelligencer, but not to $J B S$ ): members, $\$ 38.00$; students, $\$ 22.00$. Canada: members, $\$ 42.80$; students, $\$ 23.54$. JBS SUBSCRIPTION ONLY: USA: institutions, $\$ 97.00$; nonmember individuals, $\$ 48.00$. Canada: institutions, $\$ 106.29$; nonmember individuals, $\$ 53.86$. Outside the United States and Canada, add $\$ 2.50$ for postage for each year's subscription. Subscription agent for Japan: Kinokuniya Co., Ltd. Individuals have the option to order directly from the University of Chicago Press. SINGLE COPIES: institutions, $\$ 24.25$; individuals, $\$ 12.00$. INQUIRIES AND PAYMENTS for membership and/or subscriptions should be addressed to Journal of British Studies, The University of Chicago Press, P.O. Box 37005, Chicago, Illinois 60637. For subscription information, write; fax, 773/753-0811; or e-mail, subscriptions@journals.uchicago.edu.

Postmaster: Send address changes to Journal of British Studies, The University of Chicago Press, P.O. Box 37005, Chicago, Illinois 60637.

Editorial correspondence should be sent to the Editor, Journal of British Studies, Emory University, $1463 \mathrm{~S}$. Oxford Rd., Atlanta, Ga. 30322. Prospective authors should submit two goodquality copies of the manuscripts to the Editor. Manuscripts not accompanied by return postage will not be returned. All unsolicited manuscripts must be prepared by the author for blind review; that is, all indications of the author's name and institutional affiliation must be removed from the text, header, footer, and notes prior to submission. Articles should conform to The Chicago Manual of Style (14th ed.). The entire text of manuscript, including quotations and endnotes, must be typed double-spaced with generous margins. Do not justify the right margin. Footnotes should be numbered consecutively and appear at the end of the text. Further guidelines for submissions may be obtained on request from the assistant editor at the above address, or by e-mail directed to jbs@emory.edu.

Copying beyond Fair Use: The code on the first page of an article in this journal indicates the copyright owner's consent that copies of the article may be made beyond those permitted by Sections 107 or 108 of the U.S. Copyright Law provided that copies are made only for personal or internal use or for the personal or internal use of specific clients and provided that the copier pay the stated per-copy fee through the Copyright Clearance Center (CCC), 222 Rosewood Drive, Danvers, MA 01923. To request permission for other kinds of copying, such as copying for general distribution, for advertising or promotional purposes, for creating new collective works, or for resale, kindly write to Permissions Department, The University of Chicago Press, 5801 S. Ellis Ave., Chicago, IL 60637.

Advertising space in the Journal of British Studies is available, as is rental of its subscriber list. For information and rates, please contact the advertising sales staff, The University of Chicago Press, Journals Division, 5720 S. Woodlawn, Chicago, Ill. 60637. Advertising and list rental are limited to material of scholarly interest to our subscribers.

Periodicals postage paid at Chicago, Illinois, and at additional mailing offices.

(C) 1999 by The North American Conference on British Studies. All rights reserved. 